DOI http://dx.doi.org/10.18551/rjoas.2016-05.18

\title{
FARMERS' DECISION TO PARTICIPATE IN GOVERNMENT AGRICULTURAL PROGRAMMES IN A VOLATILE POLITICAL ENVIRONMENT: A CASE STUDY OF FARMERS IN THE SOUTH-SOUTH REGION OF NIGERIA
}

\author{
Sunday B. Akpan* \\ Department of Agricultural Economics and Extension, Akwa Ibom State University, Nigeria \\ Edet J. Udoh \\ Department of Agricultural Economics and Extension, University of Uyo, Nigeria \\ *E-mail: brownsonakpan10@gmail.com
}

\begin{abstract}
Most government agricultural programmes in developing countries are designed following the political ideology of the ruling class and farmers have mixed responses regarding participation. The top - bottom approach adopted in designing these programmes further created dissatisfaction among farmers. Achieving the objectives of these programmes will depend on the level of farmers' participation. Premised on this, the study determined factors that influence farmers' participation in government agricultural programmes in the Southern region of Nigeria. Data were collected from 390 farmers in the study area. Combinations of sampling methods were used to collect data. The Logit model estimates revealed that, household size, dependent ratio, farming experience, years in social organization, land ownership, awareness index, membership in political party, non-farm income, visit by extension agent, male composition in farming population and level of formal education were positive determinants of farmers' participation in government agricultural programmes in the study area. On the contrary, farm income and bureaucracy bottleneck involved in these programmes were negative determinants. Perceived constraints to farmers' participation were; bureaucracy involve; insufficient land for implementation, high transport cost and low awareness. In order to increase farmers' participation in agricultural based programme in the region, it is recommended that, government should reclaim marginal land and create a policy that will increase land ownership by resource poor farmers in the region. Farmers should be encouraged to form social groups. Massive awareness campaign should be mounted to sensitize farmers on government agricultural programmes in the region. Also, such programmes should be politically neutral and design following bottom-up approach.
\end{abstract}

\section{KEY WORDS}

Farmers, political development, agricultural development, agricultural programme.

Nigeria food import bill has continue to rise, poverty and human unemployment is rising and the primary source of revenue is losing value rapidly amidst of abundant fertile lands, favorable weather condition, active labour and commodity market among other incentives (CBN, 2014, Akpan et al., 2015). Also the continuous falling value of naira is a serious threat to food imports for now and in future. Researchers have confirmed that, the domestic agricultural production in most developing countries including Nigeria is far less than the demand capacity (Adegbola et al., 2011 and Akpan et al., 2012). The need for government intervention in increase domestic agricultural production in developing countries is overwhelmingly obvious given the prevalence of poverty, unemployment and militancy among other.

In Nigeria, governments in all tiers have recognized this significant task and have responded appropriately by enunciating several agricultural based programmes to help boost domestic agricultural production (Iwuchukwu and Igbokwe, 2012, Akinbamowo 2013). Such interventions programmes have assumed several forms such as subsidies, credit disbursement to farmers, social capital formation and guaranteeing minimum price for 
agricultural commodities. Most of these agricultural programmes design and implemented in the country have link with the ideology of the regime in power. Most of them employed the top-bottom approach with minimal input and involvement of target beneficiaries. Currently, development experts are advocating agricultural programmes that focused on bottom-up approach, view beneficiaries as partners, utilize local experience and endeavor to empower target beneficiary (Kumba, 2003).

In the South -south region of Nigeria, it is observed that, the low performance of agriculture sector has a deteriorating impact on the farmers' livelihood activities and is frequently linked to increase in poverty, huge capital flight, unemployment and malnutrition as well as militancy (Kolawole and Olufunsho 2014). Increase exploitation of crude oil and other minerals, deforestation and erosion as well as increase impact of ocean tides on shores in the region 'have constituted serious hindrances to agricultural production (Okon et al, 2014). This activity has fast track emission of dangerous gases to the atmosphere, environmental degradation, insecurity and poor yields among farmers in the region. Also high population density and rapid urbanization as well as unguided rural development are significant sources of externality costs to farmers in the region. Since more than $60 \%$ of farmers in the region have poor resource base, the need to develop and implement exogenous intervention programmes for farmers by government became necessary.

In Akwa Ibom state, the setting up of agricultural programmes by government is further justified by the aging farming population and low concentration of youths in farming (Akpabio, 2012). Some of the programmes so formed came with incentives and improved technology as well as gender sensitivity, while some focused on specific groups such as youth farmers. From 1988 till 2016, the state has implemented the following agricultural based programmes to boost food production; Rice Development Scheme, Fadamas, Akwa Ibom State Integrated Farmer Scheme, National Programme for Food Security, Women Agro-Entrepreneurship Development Programme, Commercial Agricultural Programme, Agricultural Loan Scheme, Small holder Oil Palm Development Project, Bio-fortified Cassava Stem Programme among others (Akwa Ibom State Agricultural Programme document and Akpan et al., 2015). These programmes have various objectives geared towards achieving self-food sufficiency and poverty alleviation. The physiology of each of this programme and how it is designed, political environment as well as the mandate of such programme determine the extent of farmers' participation.

Another reason that justified the formation of these agricultural programmes in the State; stem from the fact that, the quantity of food production is far below demand in the State. Following this, more than $60 \%$ of arable crop output consumed in the State is brought from other regions in the country. In addition, the political terrain in the State has change the perception of many farmers concerning farming and government programmes. Reports have shown that, most farming population is becoming politically inclined, while farmer groups have also aligned their objectives to the political agenda of the ruling regime. These have affected farmers' participation in agricultural programmes enunciated by the government.

Farmers' participation is critical, in realizing the objective of any agricultural base programme. When farmers do not have equal access or opportunity to government owned programme, it became obvious that the essence of such programme is defeated. Farmer's participation plays a vital role in economic development and in poverty alleviation (Nxumalo and Oladele, 2013). Hence, given the various conditions and the influence imposed by the political environment including other characteristics of government owned agricultural programmes, it is pertinent to identify those farmers' and environmental factors that model farmers' responses to these programmes in the state. These factors are necessary ingredients needed by policy makers to design bottom - top agricultural based programmes envisaged by the contemporary development researchers. In order to solve these problems, the study specifically determines factors (farmers' specific, environmental specific and programme specific factors) that affect farmers' participation in government agricultural programmes in the South -South region of Nigeria. 


\section{LITERATURE REVIEW}

Several researchers in developing countries have delved into issues related to farmers' participation in agricultural programmes. For instance, Badal, Pramod and Geeta (2006) examined the dimensions and determinants of peoples' Participation in Watershed Development Programmes in Rajasthan. Using Tobit regression, the result revealed beneficiary participation was positively encouraged by training of the farmers, farmers' age, and frequency of visits by the extension workers. A negative relationship was found between participation and off-farm income. In Nigeria, Akpan (2010) identified factors that limit rural youth involvement in agricultural production. He divided these factors into economic, social and environmental factors. Economic factors included; inadequate credit facilities, low farming profit margins, lack of agricultural insurance, insufficient initial capital and production inputs. Social factors were; public perception about farming and parental influence to move out of agriculture. Environmental issues were; inadequate land, continuous poor harvests, and soil degradation. In Ghana, Etwire et al., (2013) examined factors influencing farmer's participation in agricultural value chain mentorship project in the northern region. The study adopted the binary probit model and results indicated that number of years in school, access to production credit and agricultural extension service were factors that significantly determined farmer's participation. Also, Martey et al., (2013), presented empirical findings that quantify factors influencing participation in rice development projects among smallholder rice farmers in Northern Ghana. The result revealed that, participation in rice development projects in the region was influenced by age of the household head, marital status, access to off-farm income, market price of rice, knowledge of rice varieties and access to credit and the interactive terms like education and farm size.

In South Africa, Nxumalo and Oladele (2013) examined factors affecting farmers' participation in agricultural projects in Zululand district, KwaZulu Natal Province. The Probit regression estimates revealed that, land ownership, age, household head and non-farm income were important determinants of farmers' participation. The result also showed that, unavailability of land, lack of funds and limited resources were major constraints against participation. Tologbonse, Jibrin, Auta and Damisa (2013) conducted a research to determine women farmers' participation in women in agriculture (WIA) programmes of Kaduna State Agricultural Development Project, Nigeria. The multiple regression based on ordinary least square method revealed that, marital status, level of education, access to extension service and market availability were the major determinants of women participation. Ohene (2013) examined determinants of farmers' participation in youth-inagriculture programme in the eastern region of Ghana. The Logit analysis reveals that the main determinants of participation in youth in agriculture programme are respondents' age, education, household size, farm size, farm income, access to credit, membership of an FBO, location and distance from their house to the site of the programme.

Sithole, Job and Micah (2014) studied factors influencing farmers participation in smallholder irrigation Schemes in Ntfonjeni rural development Area in Swaziland. The study revealed that the participation in small holder irrigation scheme was significantly influenced by households' distance to the scheme site, age and occupation of household head, farm size and access to credit and; membership in other groups. Nwaobiala (2014) identified socio-economic factors influencing farmers' participation in community- based programme in Abia and Cross River States of Nigeria. The Probit regression identified positive motivators like; age and farming experience and gender. However, farm size was negatively related to farmers' participation. The study also identifies significant constraints to farmers' participation such as; negative perception of farmers on past and similar programmes, bad road network and administrative bottlenecks and bureaucracy involved in the programme.

Akpan et al., (2015) carried out a research on the determinants of decision and participation of rural youths in agricultural production in Southern region of Nigeria. The Logit model estimates revealed that years of youths in social organization, access to ICT, nature of land ownership, and youth access to state owned agricultural programme were positive determined of decision of youths to engage in agricultural activities in the study area. On the 
contrary, male youths, years of formal education and marital status of youths were negative determinants. In an attempt to mainstream gender sensitivity into this line of research, Temesgen, Umer and Jamal (2015) conducted a study to determine factors influencing participation of women in agricultural extension training programs. The study applied binary model to identify factors affecting women participation in modular training program. The Logit model results revealed that family labor, information seeking behavior and extension contact had significant and positive influence on participation of women farmers in modular training programs.

Research Gap discovered in the Literature. Information from the pool of literature so far have not considered the political environment prevalence in the area of study. The wind of democracy blowing across the developing countries has great impact on the ideology and perception of farmers now compared to what existed before. For instance, some farmers' cooperatives or groups (e.g. Youths in Agriculture) played important role during election in Nigeria. Hence, there is an overwhelming need to incorporate variable representing political volatility in the model meant to study farmers' participation in agricultural programme.

\section{CONCEPTUAL AND MATHEMATICAL FRAMEWORKS}

The conceptual framework of the study is found in the consumer's utility theory. A farmer is a rational being that maximizes satisfaction subject to several constraints. In this model, it is assumed that farmers have mutually exclusive discrete choice of participating in government agricultural programme or choose not to participate. A farmer choice is conditioned on the magnitude of expected utility from the programme. Following consumer behaviour theory, the satisfaction a typical consumer derived from consumption of nth commodity consists of two major components: these are the deterministic element (Uim) that is observable and the random error ( ) which is unobservable (Udoh et al., 2008). Given that, utility that a farmer derives with and without government agricultural programme is given as $U i$ and $U m$ respectively, then the nth farmer will participate in government agricultural programme only if $U i>U \mathrm{~m}$. Consequently, the probability $P_{n}$ that nth farmer will participates in the programme can be expressed as follow:

$$
P_{n}=\left(U_{i}+\varepsilon_{i}>U_{m}+\varepsilon_{m}\right)
$$

The inequality in the bracket is conditioned by several factors ranging from budget constraint, environmental factors, socio-economic factors among others. Then, if we assume that a farmers has $\mathrm{i}+1$ alternatives, that will condition the deterministic components (Uim) then the problem of utility maximization would be:

$$
U_{t h}=\max \left(U_{i}, U_{m}, B_{n} \ldots U_{n}\right)
$$

where: $U^{*}$ the utility derived from participation which we assume discrete, $B_{n}$ represents the financial commitment and $U_{n}$ represents other variables like the socioeconomic variables. The slope of equation 2 represents the change in probability of participation of farmers resulting from a unit change in exogenous variable.

\section{RESEARCH METHODOLOGY}

The Study Area. The study was conducted in Akwa Ibom State. The state is located in the Southern region of Nigeria. It is located between latitudes $4^{\circ} 32^{1}$ and $5^{\circ} 33^{1}$ North and longitudes $7^{\circ} 25^{1}$ and $8^{\circ} 25^{1}$ east. It has a total land area of areas of $7,246 \mathrm{~km}^{2}$. The mean annual temperature of the state lies between $26^{\circ} \mathrm{C}$ and $29^{\circ} \mathrm{C}$ and average sunshine of about 1,450 hours per year. The mean annual rainfall ranges from $2,000 \mathrm{~mm}$ to $3,000 \mathrm{~mm}$, depending on the area. Maximum humidity is recorded in July while the minimum occurs in January. The state is bordered on the East by Cross River State, on the West by Rivers State and Abia State, and on the South by the Atlantic Ocean. Akwa Ibom State has a 
population of about 3,902,051 and a population density of 634 persons per square kilometers (National Population Commission, 2006). The state is basically an agrarian society where crops like maize, okra, waterleaf, cassava, yam and rice are cultivated in large quantities. Fishery including aquaculture; livestock and poultry businesses thrives well in the state. The state was picked among other states in the region because of it rich agricultural potentials and availability of survey data. In addition, the state has well demarcated rural and urban areas. Furthermore, the geography of the state supports diverse agricultural activities, in addition to has been one of the most peaceful States in region and Nigeria. The state has thirty one (31) local government areas divided into three (3) senatorial/political districts. The three Senatorial districts are: Eket district which has twelve (12) local government areas; Uyo district has nine (9) local government areas and Ikot Ekpene district has ten (10) local government areas.

Sample Size Selection. Following the work of Cochran (1963), a representative sample size from a large population of farmers in the study area was obtained using the equation (3) specified below:

$$
S_{n}=\frac{z^{2} \rho(1-\rho)}{D^{2}}
$$

where: $S_{n}$ is the required sample size; " $Z$ " is the standard normal variate (at $95 \%$ confidence interval, type 1 error; 1.96). " $P$ " is the expected proportion of farmers in the population (We assumed that $60 \%$ of the population are farmers from 1995 farm survey in the State). "D" is the absolute error or precision at $5 \%$ type 1 error.

$$
S_{n}=\frac{(1.96)^{2} 0.60(1-0.60)}{(0.05)^{2}}=369
$$

However, the study adopted proportional sampling method in the study area, hence a total of 390 (three hundred and ninety respondents) were used in the study.

Data Source and Sampling Procedures. Primary data were used and respondents were farmers (including crop and animal farmers and aquaculture). Combination of sampling methods was used to select respondents. Firstly, two local government areas with clearly distinct rural areas were purposively selected from each of the Senatorial district in the State. A total of six (6) local government areas were selected and used for data collection. In the second stage, five rural villages were randomly sampled from each of the six local government areas selected. A total of thirty rural villages were randomly sampled from the six local government areas used for data collection. In the third stage, thirteen (13) farmers were randomly picked from each of the sampled village. Hence, a total of three hundred and ninety (390) farmers were randomly sampled and used for data collection.

Empirical Model. A binary Logit model was used to identify significant factors that influence farmers' decision to participate in government agricultural programme in the study area. Implicitly, the specified model is shown in equation 5. The Logit Model which captures farmers' decision to participate in government agricultural programme is given below;

$$
\begin{gathered}
D E C=\left(\frac{P_{i}}{1-P_{i}}\right)=Z_{i}=\beta_{0}+\beta_{1} A G E+\beta_{2} G E N+\beta_{3} E D U++\beta_{4} M A R+\beta_{5} S O C+\beta_{6} I C T+\beta_{7} L A O+ \\
\beta_{8} A W A+\beta_{9} P O L+\beta_{10} N F I+\beta_{11} H H S+\beta_{12} F A E+\beta_{13} F A I+\beta_{14} B U R++\beta_{15} D E P+\beta_{16} E X T+U_{i}
\end{gathered}
$$

The marginal effect of the Logit model measures instantaneous impact that a change in a particular explanatory variable has on the predicted probability (i.e. the likelihood that a farmer in the rural area will choose to participate in government agricultural programme or not); when the other covariates are kept fixed. They are obtained by computing the derivative of the conditional mean function with respect to explanatory variables.

$$
\frac{\delta P_{i}}{\delta X_{i}}=\frac{E\{Y \mid X\}}{\delta X_{i}}=f\left(Z_{i}\right) \beta_{i}=f\left(X \beta_{i}\right) \beta_{i}
$$


Variables used in equation (5) are defined as follows:

$D E C=$ Farmer's decision to participate in government agricultural programme (dummy; 1 for yes and 0 for no); AGE = Age of a farmer (years); GEN = Farmers' gender (1 for male farmer and 0 for female farmer); EDU = Farmer's educational level (years); MAR = Marital status (unity for married and 0 otherwise); SOC = Membership of a social group (number of years); $I C T=$ Access to ICT (Number of times a farmer browse internet in a month); $\mathrm{LAO}=$ Land tenure (dummy; 1 for owned land and 0 otherwise); AWA = Awareness index (number of sources a farmers heard about the programme divided by the total number of information sources available in the state); $\mathrm{POL}=$ Political party affiliation of a farmer (dummy; 1 belongs to the ruling party and 0 otherwise); NFI = Non-farm income of a farmer in the current planting season (Naira); HHS = Household size of farm family (number); $\mathrm{FAE}=$ Farmers' farming experience (Years); FAI = Farmer's farm income (Current season farming income in Naira); BUR = Government bureaucracy involve in accessing such programme (dummy; 1 for yes and 0 for No); DEP = Dependent ratio (number of children i.e. from $0-14 y$ rs and aged i.e. above $65 y$ rs divided by the total household size); EXT = Access to agricultural extension services (number of times in the current planting season); $U=$ stochastic error term; $P_{i}=$ Probability to engage in agricultural activity; $L n=$ Natural logarithm function.

Verification of Multicollinearity among Explanatory Variables used in the Analysis. Multicollinearity is among the commonest econometric problems of the cross sectional data analysis. This property of econometric was verified among explanatory variables to ensure the econometric stability and reliability of the regression estimates. The Variance Inflating Factor (VIF) and tolerance index were estimated and used to verify the presence of multicollinearity among the explanatory variables. For VIF, the minimum possible value is 1.0; while value greater than 10 indicates a probably collinearity between the specified explanatory variable in question and the rest of the predictors in the model. According to Gujurati and Dawn, (2009), VIF is estimated using the formula stated below:

$$
V I F_{j}=\left\{1 / 1 \quad R_{j}^{2}\right\}
$$

where: $R_{j}^{2}$ represents the multiple correlation coefficient between one of the explanatory variable (designated as dependent variable) and the other specified explanatory variables in the study. The explicit model explaining the above mechanism is shown in equation 8.

$$
X_{j}=\varphi_{0}+\varphi_{1} X_{1}+\varphi_{2} X_{2}+\quad+\varphi_{n} X_{n}+\varepsilon_{n}
$$

$V I F_{j}$ has a unique relationship with the tolerance level. For instance:

$$
\text { Tolerance }=1 / V I F=\left(\begin{array}{ll}
1 & R_{j}^{2}
\end{array}\right)
$$

The higher the VIF or the lower the tolerance index, the higher the chance of collinearity.

\section{RESULT AND DISCUSSION}

Test result to verify collinearity among specified explanatory variables. Multicollinearity is a serious problem in a cross sectional study of a homogenous group, because variables tend to share similar history. Table 1 presents the Variance Inflating Factor (VIF) test results used to verify the status of the collinearity among explanatory variables used in the Logit regression estimates. The result revealed no serious collinearity among explanatory variables in the estimated model. For instance, the estimated VIF with respect to each specified variable was greater than unity, but less than the threshold value of 10 . The result suggested that, the explanatory variables specified in the Logit model do not cluster together or exhibited multi-collinearity tendencies. Also, the tolerance ratio is relatively low and falls below unity for each variable, signifying that, multicollinearity among exogenous variables is negligible. 
Table 1 - The Variance Inflation factors (VIF) and Tolerance ratio test for Multicollinearity

\begin{tabular}{|c|c|c|}
\hline Variable & Variance inflation factor & Tolerance Factor \\
\hline Age & 1.571 & 0.637 \\
\hline Household size & 1.430 & 0.699 \\
\hline Dependent ratio & 1.196 & 0.836 \\
\hline Farm experience & 1.434 & 0.697 \\
\hline Social group & 1.323 & 0.756 \\
\hline Land ownership & 1.187 & 0.842 \\
\hline Farm income & 1.180 & 0.847 \\
\hline Awareness index & 1.890 & 0.529 \\
\hline Political contact & 1.986 & 0.504 \\
\hline Access to ICT & 1.107 & 0.903 \\
\hline Bureaucracy & 1.177 & 0.849 \\
\hline Nonfarm income & 1.050 & 0.952 \\
\hline Access to Ext agent & 1.197 & 0.835 \\
\hline Gender mixed & 1.080 & 0.926 \\
\hline Marital status & 1.064 & 0.939 \\
\hline Educational level & 1.064 & 0.939 \\
\hline
\end{tabular}

Source: Computed by authors using gretl software.

This implies that the estimates of the Logit model are consistent and unbiased. In other words, the estimates of the Logit model are stable and consistent over time. This means that, the estimated coefficient represent a stable and average behaviour between the specified variable and the decision by farmers to participate in agricultural programme in the study area.

Socio-economic characteristics of respondents. The descriptive statistics of socio economic characteristics of farmers are shown in Table 2.

Table 2 - Descriptive Statistics and socio-economic of farmers in the Southern region of Nigeria

\begin{tabular}{|c|c|c|c|c|c|c|}
\hline Variable & $\begin{array}{c}\text { Minimum } \\
\text { value }\end{array}$ & $\begin{array}{c}\text { Maximum } \\
\text { value }\end{array}$ & Mean & $\begin{array}{c}\text { Standard } \\
\text { deviation }\end{array}$ & $\begin{array}{c}\text { Coefficient of } \\
\text { Variation }\end{array}$ & Skewness \\
\hline AGE & 21.00 & 65.00 & 42.449 & 8.046 & 0.189 & 0.353 \\
\hline HHS & 1.00 & 16.00 & 5.759 & 2.508 & 0.435 & 1.168 \\
\hline DEP & 0.00 & 2.00 & 0.485 & 0.385 & 0.794 & 0.817 \\
\hline FEX & 0.00 & 45.00 & 13.877 & 8.529 & 0.615 & 0.846 \\
\hline SOC & 0.00 & 25.00 & 2.267 & 4.424 & 1.952 & 2.969 \\
\hline LAO & 0.00 & 1.00 & 0.667 & 0.472 & 0.708 & -0.707 \\
\hline FAI & 0.00 & 500000 & 97009.6 & 117459 & 1.211 & 1.570 \\
\hline DEC & 0.00 & 1.00 & 0.428 & 0.495 & 1.157 & 0.290 \\
\hline AWA & 0.00 & 0.50 & 0.0952 & 0.121 & 1.275 & 1.183 \\
\hline POL & 0.00 & 1.00 & 0.459 & 0.499 & 1.087 & 0.165 \\
\hline ICT & 0.00 & 80.00 & 2.574 & 10.304 & 4.003 & 5.378 \\
\hline BUR & 0.00 & 1.00 & 0.662 & 0.461 & 0.664 & -0.846 \\
\hline NFI & 0.00 & $1.680 \mathrm{e}+006$ & 33159.6 & 97951 & 2.954 & 12.799 \\
\hline EXT & 0.00 & 1.00 & 0.821 & 0.384 & 0.468 & -1.670 \\
\hline GEN & 0.00 & 1.00 & 0.623 & 0.485 & 0.779 & -0.508 \\
\hline MAR & 0.00 & 1.00 & 0.895 & 0.307 & 0.343 & -2.575 \\
\hline EDU & 0.00 & 15.00 & 12.295 & 3.454 & 0.281 & -1.439 \\
\hline
\end{tabular}

Source: Computed by authors, 2015. Note monetary value is expressed in Naira. Variables are as defined previously.

The result revealed an average age of about 42 years for farming population in the study area. This means that, most farmers in the area are fast aging out from the active farming age. This result calls for an urgent move to encourage younger ones into farming business in the area. An average period of formal education stood at 12.30 years among respondents. This connotes that, most farmers in the area are educated, and there is high possibility of agricultural innovation adoption among them. About $62.30 \%$ of the respondents were male farmers. The result also showed that, $89.50 \%$ of farmers sampled were married. Social capital formation among farmers was low in the study area, as shown by an average 
of 2 years in social organizations. It was also discovered that, a farmer browse the internet at least of 2.5 times a month. The result further showed that, about $66.70 \%$ of farmers owned farm land either by inheritance or purchase. The rest acquired farm lands through lease and borrowed arrangement among others. An average farm income stood at $\$ 97009.60$ in the study area; whereas the non-farm income was $\$ 33159.60$. Farmers have moderate family size with a mean household size of 6 members; while extension agent visit average at 8 times per season.

The farming experience among respondents averaged at about 14 years in the study area. The result also revealed that, about $48.50 \%$ of farmers have access to various agricultural programmes initiated by the state government. Awareness index was low (less than unity) among sampled farmers; while political affiliation reached the height of $45.90 \%$ of the total sampled farmers. In addition, about $66.20 \%$ of farmers attested for the presence of undesirable and long bureaucracy bottleneck in accessing agricultural programmes in the region.

Factors that Modeled farmers Decision to Participate in Government Agricultural Programmes in Southern region of Nigeria. The Logit model estimates used to identify determinants of farmers' decision to participate in government agricultural programmes is shown in Table 3. The diagnostic statistics of the estimated Logit model revealed the pseudo $\mathrm{R}^{2}$ (McFadden $\mathrm{R}^{2}$ ) of 0.8357 . This implies that about $83.57 \%$ of variability in the dependent variable (farmers' decision to participate in government agricultural programmes) is associated with the specified independent variables. The log likelihood ratio of 445.083 is significant at $1 \%$ probability level. This indicates that, the McFadden R-squared is significant and by implication the specified Logit model has a strong explanatory power and hence goodness of fit. About $96.40 \%$ of the dependent variables were correctly predicted.

Table 3: Estimates of the Logit Model (Determinants of decision of Farmers to participate in government agricultural programme in Activities in Akwa Ibom State)

\begin{tabular}{|c|c|c|c|c|c|c|}
\hline Variable & Coefficient & $\begin{array}{l}\text { Standard } \\
\text { Error }\end{array}$ & $\begin{array}{l}\text { Marginal } \\
\text { effect }\end{array}$ & $\begin{array}{l}\text { Log odd } \\
\text { coefficient }\end{array}$ & Z-values & Prob. \\
\hline Constant & 9.3664 & 2.9869 & \multirow[b]{2}{*}{0.0143} & & $3.1358^{* * *}$ & 0.0017 \\
\hline Age & 0.0576 & 0.0616 & & 0.9440 & 0.9351 & 0.3497 \\
\hline Household size & 0.3115 & 0.1759 & 0.0774 & 1.3655 & $1.7701^{*}$ & 0.0767 \\
\hline Dependent ratio & 2.2309 & 1.0397 & 0.5544 & 9.3082 & $2.1457^{* *}$ & 0.0319 \\
\hline Farm experience & 0.1065 & 0.0522 & 0.0265 & 1.0107 & $2.0386^{* *}$ & 0.0415 \\
\hline Social group & 0.2119 & 0.0862 & 0.0527 & 1.2360 & $2.4570^{* *}$ & 0.0140 \\
\hline Land ownership & 0.9669 & 0.5648 & 0.2371 & 2.6298 & $1.7118^{*}$ & 0.0780 \\
\hline Farm income & $7.223 \mathrm{e}-06$ & $3.524 \mathrm{e}-06$ & $1.795 \mathrm{e}-06$ & 0.9999 & $2.0498^{* *}$ & 0.0404 \\
\hline Awareness index & 3.8164 & 0.6424 & 0.8539 & 45.4403 & $5.9410^{\star \star *}$ & $<0.0001$ \\
\hline Political contact & 1.9786 & 0.6848 & 0.4574 & 7.2326 & $2.8893^{* * *}$ & 0.0009 \\
\hline Access to ICT & 0.1050 & 0.0506 & 0.0261 & 1.1107 & $2.0761^{\star *}$ & 0.0379 \\
\hline Bureaucracy & 1.2359 & 0.7365 & 0.2990 & 0.29057 & $1.6781^{*}$ & 0.0933 \\
\hline Nonfarm income & $4.741 \mathrm{e}-05$ & $1.319 \mathrm{e}-05$ & $1.178 \mathrm{e}-05$ & 1.0000 & $3.5941^{* * *}$ & 0.0003 \\
\hline Access to Ext agent & 2.9929 & 1.2353 & 0.5261 & 19.9434 & $2.4228^{* *}$ & 0.0154 \\
\hline Gender mixed & 1.3939 & 0.7703 & 0.3273 & 4.0305 & $1.8098^{*}$ & 0.0703 \\
\hline Marital status & 0.3301 & 1.1016 & 0.0823 & 0.7189 & 0.2997 & 0.7644 \\
\hline Educational level & 0.1128 & 0.0312 & 0.0280 & 1.1194 & $3.6154^{* * *}$ & 0.0002 \\
\hline \multicolumn{7}{|c|}{ Diagnostic Statistics } \\
\hline Mean dependent Var. & \multicolumn{2}{|l|}{0.4282} & \multicolumn{3}{|c|}{\begin{tabular}{l|l} 
& S.D. dependent Var. \\
\end{tabular}} & 0.4955 \\
\hline McFadden $\mathrm{R}^{2}$ & \multicolumn{2}{|l|}{0.8357} & \multicolumn{3}{|c|}{ Adjusted R-squared } & 0.7719 \\
\hline Log-likelihood & \multicolumn{2}{|l|}{43.7516} & \multicolumn{3}{|c|}{ Akaike criterion } & 121.5031 \\
\hline Schwarz criterion & \multicolumn{2}{|l|}{188.9276} & \multicolumn{3}{|c|}{ Hannan-Quinn } & 148.2306 \\
\hline $\begin{array}{l}\text { Likelihood ratio test: } \\
\text { Chi-square(16) }\end{array}$ & \multicolumn{2}{|c|}{$445.083[0.0000]$} & \multicolumn{3}{|c|}{$\begin{array}{l}\text { Number of cases 'correctly } \\
\text { predicted' }\end{array}$} & $376(96.40 \%)$ \\
\hline
\end{tabular}

Source: Computed by authors using gretl and Stata programmes, data from field survey 2015. Asterisks *, ** and ${ }^{* \star *}$ represent significant levels at 10\%, 5\% and 1\% respectively. Variables are as defined in equation 1.

The odds interpretation of results. The empirical result revealed that the odd coefficients of household size (HHS at 10\%), farmers' family dependent ratio (DEP at $5 \%$ ), 
farming experience (FAE at 5\%), membership in social organizations (SOC at 10\%), farm land ownership (LAO at 10\%), awareness index of farmers (AWA at 1\%), political affiliation of farmers (POL at $1 \%$ ), access to ICT (ICT at $5 \%$ ), non-farm income (NFI at $1 \%$ ), access to extension agent (EXT at 5\%), gender (GEN at 10\%) and educational level of farmers (EDU at $1 \%)$ are positive and statistically significant with respect to the decision or probability of farmers to participate in government agricultural programmes in the state.

The odd interpretation implies that for every unit increase in farmers' household size, dependent ratio and farming experience, the odds in favour of farmers participating in government agricultural programmes increase by 1.366 or about $36.60 \%, 9.308$ or $830.8 \%$ and 1.011 or $11.00 \%$ respectively. This means that, farmers that experienced increase in these variables are likely to participate in government agricultural programme compared to those who do not. Similarly, a unit increase in farmers' membership in social organizations and farm land ownership will lead to about 1.236 or about $23.60 \%$ and 2.629 or $162.90 \%$ increase in the log odds in favour of farmers participating in agricultural programmes launch by the state government. Also, a unit increase in awareness index will lead to about $444.03 \%$ increase in the log odds in favour of farmers participating in agricultural programme in the study area. This implies that, awareness is the most important variables affecting farmers' involvement in any agricultural programme in the State. In a similar manner, the odds of farmers engaging in government agricultural programme increases by $623.26 \%, 11.07 \%$ and remains stationary at $0 \%$ for every unit increase in political party affiliation, access to ICT and non-farm income of farmers respectively. The result further revealed that, a unit increase in extension service, number of male farmers and years of formal education increase the odds coefficient in favour of farmers' participation by $189.43 \%, 303.05 \%$ and $11.94 \%$ respectively.

On the contrary, the result showed that, a unit increase in farmers' income and bureaucracy in accessing the programmes is related negatively to the odds of farmers' participation in government agricultural programmes in the state. For instance, every unit increase in farmers' income and bureaucracy will reduce the odds in favour of farmers participating in government agricultural programmes by 0.9999 or about $0.010 \%$ and 0.7189 or $28.11 \%$ respectively.

Probability or Marginal effect/slope interpretation of Results. The result showed that, a unit increase in farmers' household size, dependent ratio and farm experience will respectively increase the probability of farmers participating in government agricultural programmes by $0.077,0.554$ and 0.027 . Given this result, farmers' dependent ratio is one of the key determinants in participation in any agricultural programme in the state. In a similar way, about $5.3 \%$ and $23.71 \%$ increase in the probability of farmers' involvement in government programme is obtained for every 100 units increase in membership in a social organization and number of farmers that own land. This result portrays the important of land ownership among beneficiaries of government agricultural programmes in the state. In addition, $10 \%$ increase in farmers' awareness index, political affiliation and access to ICT will lead to $8.54 \%, 4.57 \%$ and $0.26 \%$ increase respectively in the probability of farmers' participating in government agricultural programme in the state. By this result, it means that awareness index is the most important determinant of the decision of farmers to participate in government agricultural programme in the State. Similarly, a unit increase in extension agent visit, male composition in the farming population and educational level of farmers increases the probability of participation by $0.526,0.327$ and 0.028 respectively. However, a marginal increase in the probability of participation was obtained due to increase in non-farm income.

On the other hand, a unit increase in farm income marginal reduces the probability of participation. Likewise, increase in bureaucracy depreciates the probability of farmers' participation by 0.299 .

\section{DISCUSSION OF RESULTS}

The positive determinants of the odds in favour of farmers' participation in government programme satisfied a priori expectations. For instance, increase in household size and dependent ratio of farmers is likely to increase household expenditure. This has a negative 
influence on farm income, as some portion of the farm income could be allocated to household expenditures. Since majority of farmers in the region have poor resource endowment, increase in household expenditure will constrain farm budget and this will justify the need for exogenous funding and or subsidies in form of government programme. This result corroborates the finding of Martey et al., (2013), Nxumalo and Ladele (2013), Sithole, Job and Micah (2014) as well as Akpan et al, 2015.

Also increase in farming experience and years in a social organization among farmers, promote social capital formation or networking among farmers and technology adoption respectively. Knowledge, ideas and experiences shared among members of a social group encourages adoption of technology. The social interaction among members helped to sustained their believed and confident in their occupations as well as adoption of technology. Groups that shared the same occupation will easily encourage one another to stay put in their occupation and embrace innovation like government agricultural programme. Similar reports have been reported by Nwaobiala (2014), Ohene (2013) and Akpan et al 2015.

In addition, increase ownership of farm land increases the probability of farmers' engagement in agricultural activities and hence agricultural programmes in the State. This result is predicated on the fact that, land is one of the prerequisites for benefitting from most government agricultural programmes in the state. Land is often used as collateral for credit based programmes and as a condition to participate in arable crop based programme in the State. This result perhaps suggests that, farmers decision to participate in any agricultural based programme in the State is significantly depended on the fact that, increase in land ownership among farmers will likely reduced the cost of production, show seriousness of intended beneficiary and probably expand farm's level profit. This result is in consonance with the previous reports submitted by Martey et al., (2013), Nxumalo and Ladele (2013), Sithole, Job and Micah (2014) and Akpan et al 2015.

The result further revealed that, farmers' awareness index is the most important factor that positively influences farmers' participation in government agricultural programme in the state. This means that, appropriate and timely information is the key that could unlock the pathway through which farmers can massively benefitted from government agricultural programme in the region. The result implies that, increase awareness will likely boost farmers' interest and the need to try any new technology. Temesgen, Umer and Jamal (2015) found similar result in Ethiopia.

Membership in political party or involvement in any political movement increases the chance of farmers' participating in government agricultural programme in the region. The result shows that, farmers interest in politic increases the probability of participating in agricultural programme by 0.457 . The result satisfies the priori expectation, because most of these agricultural programmes have political undertone. Some political parties' have established some of these programmes to attract supporters and compensate their supporters. This implies that, farmers' who belong to the ruling political party or show allegiance have high probability to benefit from such programmes than those outside the ruling party. In most cases, the beneficiaries represent party's faithful or loyalists. Akpan et al 2015 confirmed this result for youth farmers in Nigeria.

Also, increase access to ICT facility promotes social interaction among farmers. It helps to increase awareness index of farmers. Hence, the positive relationship between probability of participation and increase access to ICT is as the result of promptly and efficient information transfer. Akpan et al 2015 has reported similar result in southern Nigeria.

The result also supported positive relationship between farmers' probability of participation and the non-farm income among farmers in the region. This result is premised on the fact that, farmers are rational. This means that, farmers that make profit will always be hunger for increase farm profit or expansion of non-farm income. This is necessary in order to create a sort of insurance to farm income when household expenditure expands. Hence, adopting technology that will increase their farm level profit will be paramount in their scale of preference. Thus, because of the urge for continuous increase in income; farmers will always go for improved technology or programme that will enhance their revenue based. The finding 
agrees with Nxumalo and Ladele (2013) result, but is contrary to the finding of Badal, Pramod and Geeta (2006).

Increase number of visits by extension agent(s) likewise increases the probability of participation of farmers' in government agricultural programme in the study area. Agricultural extension agents are change agents. Apart from disseminating farming information, they also sold government programmes to farmers. This implies that, a vibrant agricultural extension is a good source through which farmers can be attracted to government agricultural programmes in the State. The result is in line with empirical results generated by the following; Badal, Pramod and Geeta (2006), Etwine et al., (2013), Tologbonse, Jibrin, Auta and Damisa (2013) and Temesgen, Umer and Jamal (2015) as well as Akpan et al 2015.

The slope coefficient of gender also indicates a positive relationship between participation and male composition in farmers' population in the study area. About $32.73 \%$ increase in probability of participation is obtained for every $10 \%$ increase in male farmers in the area. This result implies that, male farmers have strong interest in government agricultural programmes compared to female counterpart. The result could be linked to the role male farmers' played in the household. Cultural, social and environmental reasons could also be responsible for this result as asserted by Akpan (2010).

Furthermore, a unit increase in education of farmers increases the odd of farmers' participation in government agricultural programme. Alternatively, a year increase in formal education of farmers increases the probability of participation in agricultural programme by 0.028. The result suggests that, as farmers acquired more years of formal education, their tests and preferences for farming grew. In addition, most of these modern agricultural programmes required some levels of formal education as one of the conditions for intended beneficiaries. The finding indicates that, the absent of educational facilities in the rural areas could be a serious push factor that militates against farmers participation in agricultural programmes in the State. The following have reported similar result in their respective researches: Etwine et al., (2013), Martey et al., (2013), Tologbonse, Jibrin, Auta and Damisa (2013), Ohene (2013) and Akpan et al 2015.

On the contrary, the negative relationship between farmers' decision to participate in agricultural programme and farm income as well as bureaucracy bottleneck satisfy priori expectation. For instance, continuous increase in farmers' farm income will likely put a farmer in an equilibrium or satiable state. This means that, they will likely derive incentive in their present technology than the anticipating one; hence the choice of adopting new technology might not just be there. Also, too many procedures accompanying any government agricultural programme will definitely deter the farmers' interest. This is because, most farmers are not learned enough to withstand the rigor involve in the whole programme. Another issue is related the cost of transportation and the resources needed to finance lengthen procedures. Concerning farm income Nwaobiala (2014) has reported similar result while Ohene (2013) earlier opposes this finding.

Perceived Constraints to Farmers' participation in Government organized Agricultural programme in Akwa Ibom State, Nigeria. Responses of sampled farmers regarding factors militating against their participation in government agricultural programmes were descriptively analyzed and presented in Table 4. Qualitative tools such as percentages and ranking were employed to identify and rank constraints in a descending order. From the ranking, the result revealed that, Bureaucracy involved in assessing these programmes $(66.21 \%)$ is the most important perceived constraint faced by farmers in the region. Another important constraint identified was insufficient land needed for implementation of the programme $(64.86 \%)$. The next important constraints were, high transport cost during documentation and training $(61.49 \%)$ and low awareness or sensitization $(60.81 \%)$. These constraints stem from incessant hike in fuel prices and poor mass media coverage in the state. Respondents also attributed frequent electricity failure to issues related to poor mass media coverage.

Long distance to the head office (54.05\%) and discriminatory tendencies exhibited by government officials (53.37\%) also constituted perceive hindrances to farmers' participation in government agricultural programmes in the state. Most rural base farmers identify poor 
road network that link rural to urban areas as a serious issue. The farmers' also perceived that, ethnic/tribal discrimination $(52.03 \%)$, insufficient collateral $(52.03 \%)$ and programme inconsistency (49.32\%) as well as political party discrimination (45.95\%) are other significant deterrents to farmers' participation in government agricultural programmes in the region.

In addition, the study identified poor training during the programme $(45.27 \%)$ and Gender insensitivity of govt. Agricultural programmes (40.54\%) as well as Farmers' low educational level $(39.86 \%)$ as mild constraints to farmer's participation in government agricultural programme in Akwa Ibom State.

Table 4 - Constraints to Farmers' Participation in Government Agricultural Programme in Akwa Ibom State, Nigeria

\begin{tabular}{|l|c|c|}
\hline \multicolumn{1}{|c|}{ Constraint } & Percentage & Ranking \\
\hline Bureaucracy involved & 66.21 & 1 \\
\hline Insufficient land for implementation & 64.86 & 2 \\
\hline High transport cost & 61.49 & 3 \\
\hline Low awareness or sensitization & 60.81 & 4 \\
\hline Low awareness or sensitization & 54.05 & 5 \\
\hline Discriminatory tendencies exhibited by govt. officials & 53.37 & 6 \\
\hline Ethnic/tribal discrimination & 52.03 & 6 \\
\hline Insufficient collateral & 52.03 & 7 \\
\hline Programme inconsistency & 49.32 & 8 \\
\hline Political party discrimination & 45.95 & 9 \\
\hline Poor training during the programme & 45.27 & 10 \\
\hline Gender insensitivity of govt. Agricultural programmes & 40.54 & 11 \\
\hline Farmers' low educational level & 39.86 & 12 \\
\hline Frequent Conflict in our domains & 33.11 & 13 \\
\hline Incompatible technology in the package & 32.43 & 14 \\
\hline
\end{tabular}

Source: Computed by authors, 2016.

Other less important perceived constraints identified included; Frequent Conflict in our domains $(33.11 \%)$ and Incompatible technology in the package $(32.43 \%)$. Several authors have reported similar result in different locations. Examples are: Akpan 2010, Nxumalo and Ladele (2013) and Akpan et al., (2015).

\section{SUMMARY OF FINDINGS, CONCLUSION AND RECOMMENDATIONS}

The study focused on the identification of factors that affect farmers' participation in government agricultural programme in the South - South region of the Nigeria. Emphasis was placed on the volatility in political environment in which farmers in the region operate in. The descriptive analysis revealed an average age of about 42 years for farming population in the study area. An average period of formal education stood at 12.30 years among respondents. About $62.30 \%$ of the respondents were male farmers. The result also showed that, $89.50 \%$ of farmers sampled were married. Social capital formation among farmers was low in the study area, as shown by an average of 2 years in social organizations. The result further showed that, about $66.70 \%$ of farmers owned farm land either by inheritance or purchase. An average farm income stood at $\mathbf{N 9 7 0 0 9 . 6 0}$ in the study area; whereas the nonfarm income was $\$ 3159.6$. Farmers have moderate family size with a mean household size of 6 members; while extension agent visit average at 8 times per season.

The empirical result based on maximum likelihood estimation of Logit model revealed that household size, farmers' family dependent ratio, farming experience, membership in social organizations, farm land ownership, awareness index of farmers, political affiliation of farmers, access to ICT, non-farm income, access to extension agent, number of male farmers and educational level of farmers have positive and significant relationship with the decision or probability of farmers participating in government agricultural programmes in the state. On the other hand, farm income and bureaucracy bottleneck were inversely related to the probability of farmers participation. Descriptively, constraints hindering farmers' participation in government agricultural programmes were identified and arrange in 
ascending order as thus; bureaucracy, insufficient farm land, high transport cost and low awareness. Others include; long distance to the head office, discriminatory tendencies, poor road network, ethnic/tribal discrimination, insufficient collateral and programme inconsistency among others.

Increase farmers' participation in government agricultural programme is one way to measure the acceptable and workability of government policies in agriculture. And this can also be seen as one reliable way of managing food insecurity and curbing excess unemployment among active population. The country needs a drastic policy reformation in agriculture in order to change the current import dependent agriculture to self-sufficient agricultural production. This will require a holistic policy package that will focus on issues related to the physical and political environments and socio-economic factors of farmers among others.

Based on findings of the research, the following recommendations were proposed:

Government should as a matter of policy reclaim marginal land and create a policy that will increase land ownership by resource poor farmers in the region.

Farmers should be encouraged to form social groups, while government, individual, communities; NGOs should collaboratively strengthen and empowered theses groups for efficient networking.

Massive awareness campaign should be mounted by various government agencies, media outfit and other organs of government to sensitize farmers on government agricultural programmes in the state.

Agricultural programmes in the region should be design with ideology of political neutrality. We suggest that, such programme should be self-sustaining and not hinge on the political framework of the ruling party. This will eliminate favourism in selection and implementation.

As a way to encourage farmers' participation in government agricultural programmes in the state, we suggest that agricultural extension services should be strengthen and appropriate attention given to the provision of ICT facilities.

Provision of electricity, health centers, recreational centers and modern water supply in the rural areas are reliable and sure means of settling youth in the rural areas.

Government agricultural programme should be simple void of unnecessary drudgery and long administrative bottleneck.

Education is a positive motivator of farmers' participation in government agricultural programmes in the State, hence adult education programmes should be strengthens in addition to providing standard education facilities for youth farmers in the rural areas of the state.

It is suggested that, government of the region should develop family welfare scheme for farmers in the region. This will helped to cushion the effect of expanding family expenditure and reconfigure the farming household head to adopt better technology.

\section{REFERENCES}

1. Adegbola J. A., Bamishaiye E. I., and Daura A. M. (2011). Food security in Nigeria: Government's intervention and the place of effective storage. Asian Journal of Agriculture and Rural Development, 1(2), 56-63.

2. Akinbamowo, R. O., (2013). A review of government policy on agricultural mechanization in Nigeria. Journal of Agricultural Extension and Rural Development; 5(8), pp. 146-153.

3. Akpabio, I. A. (2012). Youth employment and agricultural Development: the inextricable Siamese twins. $34^{\text {th }}$ Inaugural lecture Series of the University of Uyo, Nigeria.

4. Akpan, S. B., (2010). Encouraging Youth Involvement in Agricultural Production and Processing in Nigeria. Policy Note No. 29: International Food Policy Research Institute, Washington, D.C.

5. Akpan, S. B., Ini-mfon V., Glory E. and Daniel E., (2012). Agricultural Productivity and Macro-Economic Variable Fluctuation in Nigeria. International Journal of Economics and Finance; Vol. 4, No. 8; Pp. $114-125$. 
6. Akpan, S. B., Inimfon V. Patrick, Samuel U. James and Damian I. Agom (2015). Determinants of decision and participation of rural youth in agricultural production: a case study of youth in southern region of Nigeria. Russian Journal of Agriculture and SocioEconomic Sciences, 7(43), Pp.35 - 48.

7. Badal, P. S., Pramod K. and Geeta B., (2006). Dimensions and Determinants of Peoples' Participation in Watershed Development Programmes in Rajasthan. Agricultural Economics Research Review Vol. 19; Pp. 57-69.

8. Cochran, W.G. 1963. Sampling Techniques, 2nd Ed., New York: Wiley and Sons, Inc.

9. Etwire, P. M., Wilson D., Alexander N., Edward M., Eunice E., Robert K., and Esther W., (2013). Factors Influencing Farmer's Participation in Agricultural Projects: The case of the Agricultural Value Chain Mentorship Project in the Northern Region of Ghana. Journal of Economics and Sustainable Development, Vol.4, No.10, Pp. $36-43$.

10. Iwuchukwu, J. C and Igbokwe, E. M., (2012). Journal of Law, policy and Globalization, Vol. 5, Pp. $11-21$.

11. Kolawole, B. O., and Olufunsho A. O., (2014). Raging Poverty and Agricultural Output in Nigeria: An Empirical Investigation. Journal of Economics and Sustainable DevelopmentVol.5, No.6, Pp. 63 -72.

12. Kumba, F. F. (2003). "Farmer Participation in Agricultural Research and Extension Service in Namibia". Journal of International Agricultural and Extension Education 10(3): 47-55.

13. Martey, E., Alexander N. Bright O., Kwame A., Wilson D. and Ramatu M. (2013). Factors influencing participation in rice development projects: the case of smallholder rice farmers in northern Ghana. International Journal of Development and Economic Sustainability; Vol. 1, No. 2, pp. 13-27.

14. Nwaobiala, C. U., (2014). Socio-Economic Factors Influencing Farmers' Participation in Community- Based Programme in Abia and Cross River States of Nigeria. Journal of Agricultural Extension Vol. 18(1); pp. 48-51.

15. National Population Commission document (2006). Publications. Retrieved from http://www.qtsnigeria.com. On the $27^{\text {th }}$ of February, 2015.

16. Nxumalo, K. K., and Oladele, O. I., (2013). Factors Affecting Farmers' Participation in Agricultural Programme in Zululand District, Kwazulu Natal Province, South Africa. J Soc. Sci., 34(1): 83-88.

17. Ohene, V. F., (2013). Determinants of farmers' participation in the youth-in-agriculture programme in the eastern region of Ghana. Unpublished Master Thesis of the department of agricultural economics and agribusiness college of agriculture and consumer sciences University of Ghana, legion.

18. Okon, U. O., Christopher A. Ekpo, Sunday B. Akpan, Otu W. Ibok and Nsikan E. Bassey (2014). Analysis of the Expectations and Benefits of Petroleum Resource Exploration in Oil Producing Communities of Akwa Ibom State, Nigeria. International Journal of Management Sciences and Business Research. Vol-3, Issue 12, Page, 7 - 12.

19. Sithole, N. L., Job K. Lagat and Micah B. Masuku (2014). Factors Influencing Farmers Participation in Smallholder Irrigation Schemes: The Case of Ntfonjeni Rural Development Area of Swaziland. Journal of Economics and Sustainable Development Vol.5, No.22, Pp. $157-167$.

20. Temesgen, D., Umer H., Jamal Y. (2015). Determinants of farm women participation in agricultural extension training programs: A case from selected district of Oromia Region of Ethiopia. International Journal of Agricultural Science Research, 4(4), pp. 067-077

21. Tologbonse, E. B. ; Jibrin M. M., Auta, S. J., and Damisa, M. A., (2013). Factors influencing women participation in Wome Int. J. Agric. Econ. Extension $\mathrm{n}$ in Agriculture (WIA) Programme of Kaduna State Agricultural Development Project, Nigeria. Int. J. Agric. Econ. Extension; vol 1 (7):pp. $47-54$.

22. Udoh, E. J., B. T. Omonona and Nkoyo E. Bassey (2008). Circumstances and Choices: A Case of Treatment Alternatives for Malaria Diseases among Fishing Households in the Rainforest Region of Nigeria. European Journal of Social Sciences - Volume 6, Number $3,451-458$. 